\title{
OPERATION EVALUATION METHOD FOR MARINE TURBINE COMBUSTION ENGINES IN TERMS OF ENERGETICS
}

\author{
Marek Dzida, Prof. \\ Jerzy Girtler, Prof. \\ Gdansk University of Technology, Poland
}

\begin{abstract}
An evaluation proposal (quantitative determination) of any combustion turbine engine operation has been presented , wherein the impact energy occurs at a given time due to Energy conversion. The fact has been taken into account that in this type of internal combustion engines the energy conversion occurs first in the combustion chambers and in the spaces between the blade of the turbine engine. It was assumed that in the combustion chambers occurs a conversion of chemical energy contained in the fuel-air mixture to the internal energy of the produced exhaust gases. This form of energy conversion has been called heat. It was also assumed that in the spaces between the blades of the rotor turbine, a replacement occurs of part of the internal energy of the exhaust gas, which is their thermal energy into kinetic energy conversion of its rotation. This form of energy conversion has been called the work. Operation of the combustion engine has been thus interpreted as a transmission of power receivers in a predetermined time when there the processing and transfer in the form (means) of work and heat occurs. Valuing the operation of this type of internal combustion engines, proposed by the authors of this article, is to determine their operation using physical size, which has a numerical value and a unit of measurement called joule-second [joule $x$ second]. Operation of the combustion turbine engine resulting in the performance of the turbine rotor work has been presented, taking into account the fact that the impeller shaft is connected to the receiver, which may be a generator (in the case of one-shaft engine) or a propeller of the ship (in the case of two or three shaft engine).
\end{abstract}

Keywords: work, Hamilton work, Maupertius work, energy, turbine combustion engine

\section{INTRODUCTION}

Many publications regard the issue of marine diesel engines with piston ignition. This work is interpreted as the work conversion in the form of heat and energy work $E$ of the engine and the transmission to the receiver at a given time $t[3,17,18,19]$. The action interpreted this way of this type of engine (in evaluative terms) is determined by a physical quantity that has a possible to determine numerical value and unit of measure called joule-second [joule $\times$ second]. One can consider the operation of marine turbine combustion engines in a similar way.

Such an interpretation of the operation of marine diesel engines, both piston and turbine is the result of the method of analogy, enabling the transfer of insights from one object of research (empirical system) to another. The inspiration for the considerations made in this article on the effects of these internal combustion engines have been proposed by P.L. Maupretius and W.R. Hamilton for the operation of mechanical system. They proposed that the operation of such systems should be considered as a physical quantity that describes the change in mechanical energy over time. As a result, classical physics is known to act as an interpretation result of the energy changes in time, expressed as a product of energy and time, which makes the unit of measurement of the activity a joule-second $[22,24]$. The authors assumed that the same effect may be considered for internal combustion engines with the difference that the concept of energy is 
generalized as it is understood in thermodynamics. Therefore, it is assumed that the energy $(E)$ is a scalar characterizing the state of the internal combustion engine, both the piston and also the turbine. Energy, as the property of these engines, like and thermodynamic system, can be disclosed only if it is transformed in a way (form) of heat and / or work. For this reason, it is assumed that the heat and work execution are possible. In these engine types one can distinguish in addition to mechanical energy, e.g. Linear motion of the piston (combustion piston engines) or rotation (with the rotor of the turbine and the compressor turbine engine), such types of energy as chemical energy of fuel or air or a mixture of air-fuel internal energy of exhaust gas, thermal energy, radiant energy emitted into the environment during operation of the engine, etc. As a result, it was concluded that it would be interesting to take the problem of valuation of work of a turbine combustion engine, for example, the engine used for ship propulsion.

\section{FORMULATION FO THE PROBLEM OF VALUATING THE PERFORMANCE OF A TURBINE COMBUSTION ENGINE}

The basis to make a consideration of the determination of the work of marine turbine combustion engines, as well as operation of marine piston engines for main ship propulsion $[2,3,5,6,7,8]$, were the works of W. R. Hamilton and P. L Maupertius $[22,24]$. The Hamilton work $\left(D_{H}\right)$ refers to the work of mechanical system, which causes the simultaneous change of kinematic and potential Energy, whilst the Maupertius work $\left(D_{M}\right)$ refers to a change only of the kinetic energy of the mechanical system.

Hamilton work considered in classical mechanics when dealing with equations of motion of a mechanical system (system of material points), is expressed by formula [10, 22, 24]:

$$
D_{H}=\int_{t_{1}}^{t_{2}} E_{H} \mathrm{~d} t, \quad E_{H}=E_{k}-E_{p}
$$

where:

$E_{H}$ - energy, so called Lagrange function (lagrangian), $E_{k}$ - kinetic energy, $E_{p}$ - potential energy.

A similar analytical for has the Maupertius work, which is expressed as follows [10, 22]:

$$
D_{M}=\int_{t_{1}}^{t_{2}} 2 E_{k} \mathrm{~d} t
$$

In physics, the operation is interpreter as the value which is the size of the multiplication of the momentum and the displacement of the body [22]. Such action can be expressed by the formula:

$$
D_{p}=\int_{t_{1}}^{t_{2}} p s \mathrm{~d} t=\int_{t_{1}}^{t_{2}} m v s \mathrm{~d} t=\int_{t_{1}}^{t_{2}} m a s t \mathrm{~d} t=\int_{t_{1}}^{t_{2}} F s t \mathrm{~d} t
$$

where:

$p$ - momentum, $s$ - distance, $m$ - mass, $v$ - speed, $a$ - acceleration, $F$ - force, $t$ - time
The action specified by equation (3) may be important in maritime transport. It can be characterized by the energy demand needed to overcome the difficulties of stopping of a ship in motion, appearing on the collision course with other ships. Form the considerations referenced in publication [21], a cargo ship (for example) travelling at a speed of $16 \mathrm{w}$ $(\sim 30 \mathrm{~km} / \mathrm{h})$ will be stopped after $5000 \mathrm{~m}$, when breaking does not use the main engine of the ship and $950 \mathrm{~m}$ when the main ship engine is used. Formula (3) allows to ascertain, how much value of the energy $(E)$ is needed for the ship to do the work $(L)$ on at a certain way for it to stop and avoid collision with another ship or hydraulic structures located on the course of the ship, which should be stopped.

In quantum mechanics, the equivalent operation is the Planck constant $(h)$, which specifies the ratio of energies of a time quanta of electromagnetic radiation $\left(E_{v}\right)$ of the frequency $v$. Thus a source of radiation that may be represented by the following formula $[10,12]$ :

$$
h=\frac{E_{v}}{v}
$$

A characteristic feature of such activities is that they are physical quantities of the unit measurement, which is joulesecond [Js]. The same effect can be interpreted in a turbine combustion engine, that is, as the conversion in it and transfer of Energy by this engine while taking into account the time.

Operation of each turbine combustion engine may be considered in deterministic and probabilistic terms. In the deterministic approach, where the energy $E$ does not change within the time interval $[0, t]$, the action $(D)$ of such an engine can be expressed as the following formula [11]:

$$
D=E t
$$

For a case when the energy $(E)$ depends on the time $(t)$, the action $D=D(t)$ must be determined from the relationship:

$$
D(t)=\int_{0}^{t} E(\tau) \mathrm{d} \tau
$$

where:

$E(t)$ - energy converted during the operation of the engine at time $t$,

$[0, \tau]$ - time interval during which the engine is operational.

During the operation of the engine, Energy is disclosed at the time of its transformation, which takes two forms of work or heat. Therefore, the effect of turbine combustion engine interpreter according to the formula (6) can also be expressed as formulas, in which the under-integral functions are work $(L)$ and heat $(Q)[9]$ :

$$
D_{L}(t)=\int_{0}^{t} L(\tau) \mathrm{d} \tau \quad D_{Q}(t)=\int_{0}^{t} Q(\tau) \mathrm{d} \tau
$$

where:

$D L(t)$ - action connected with work in time $t$,

$D Q(t)$ - action connected with heat transfer in time $t$,

$[0, t]$ - engine operation time interval,

$t$ - time of engine operation, which is an independent variable. 
Consideration of the operation of turbine combustion engines in this perspective seems useful because consideration of values of power of the engine based on the analysis and assessment of just how energy transfer, which is the work $(L)$ does not give full knowledge about its suitability for the job (work is a form of energy conversion). This insight gives an overall view of the processed energy $(E)$ and time $(t)$ of its processing, which is the size $D(t)=E(t) \times t$, which can be called (in the valuating sense) the operation of this type of engine. Such an understanding of turbine combustion engine includes information about how long is or can energy $\mathrm{E}$ be processed. If we limit the analysis of the Energy conversion only to work (L), as a method (form) of energy conversion than taking into account the work period one can determine that the engine operation which then should be defined as $D_{L}(t)=L(t) \times t$. So understood engine operation includes information on how long work $L$ is or may be performed. It is also an important information as the one that contains the power $(N)$ of the engine, which can be determined by knowing the work $L$ and time $t$ of its conduct. As it is known, power contains information on how quickly the work $(L)$ can be done.

The interpretation of the operation of the turbine combustion engine proposed by the authors of this article has the advantage that the descriptive evaluation of the action of these engines, e.g. good, not best, disturbing etc. may be replaced by the evaluation resulting from the comparison of their performance with the benchmark of using numbers from the unit of measurements which are joule-seconds.

$D_{M_{M}} \geq D_{N W}$ In the presented aspect, the working of a turbine combustion engine may be considered as $[3,9,10,11]$ :

a) Action required $\left(D_{W}\right)$, that is, one which is necessary for the job by the turbine combustion engine being the making of the required useful work $\left(\mathrm{L}_{\mathrm{e}(W)}\right)$ demanded by the receiver, e.g. generator or ship driving propeller,

b) Action possible $\left(D_{M}\right)$, that is, one which can be achieved by a turbine combustion engine that can perform only useful work, which is feasible at his given technical condition. For this reason, work can be referred to as useful possible work $\left(L_{e(M)}\right)$.

Therefore, it can be assumed that each turbine combustion engine is capable of suitability (fit for the job), if:

$$
D_{M} \geq D_{W}
$$

In the opposite case, when $D_{W} \geq D_{M}$ one should assume, that the turbine combustion engine is in the state of unfitness, as it is unfit for the job.

\section{PROPOSAL TO DETERMINE THE PERFORMANCE OF THE TURBINE COMBUSTION ENGINE}

Turbine combustion engines with different functional structure can be installed in the power units of ships [14]. In recent years, turbine combustion engines with high energy efficiency have appeared. The company General Electric manufactures combustion turbine of type LMS 100 with a capacity of $100 \mathrm{MW}$, of which thermal efficiency reaches $46 \%$ [25]. However, these engines, apart from their energy, must have high reliability, which can be determined using wellknown theory of reliability indicators of reliability. However, these indicators refer only to time of proper operation. Taking into consideration additional relationship (8), the reliability of a turbine combustion engine can also be applied to the values resulting from the Energy equation (6) and (7). In the following discussion an example of two shaft turbine combustion engine will be presented with a heat regenerator, consisting (for example) of the following four main devices (as part of reliability) $[1,4,14]$ : compressor, combustor, turbine of combustion exhaust gas and power turbine (fig. 1).

When considering the operation of this type of engine, one can additionally consider essential equipment necessary for the smooth operation of said engine as the air filter and the heat regenerator. Such a system diagram of said machine including the air filter and the hear regenerator has been presented in Figure $2[1,4,14]$.

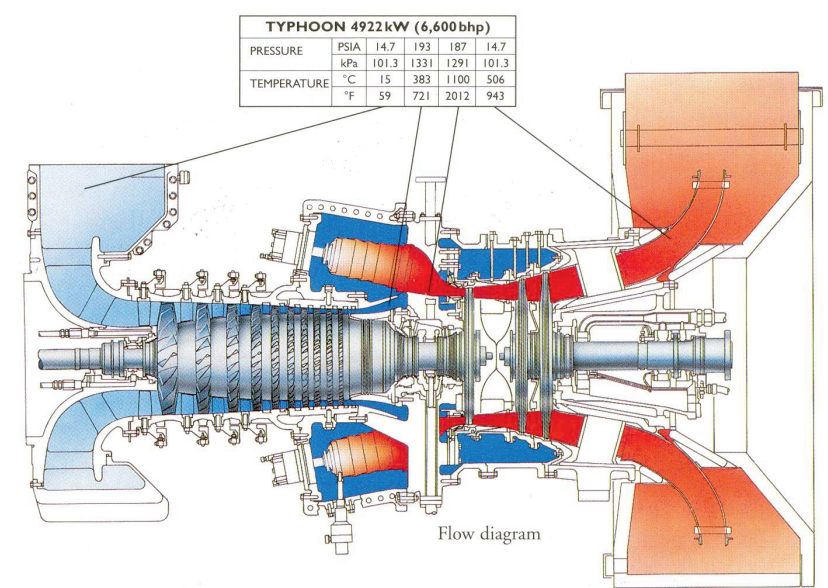

Fig. 1, Cross-section of a sample double-shaft turbine combustion engine, which elements of reliability such as compressor, combustion chamber, turbine of exhaust gas and drive turbine can be distinguished [23].

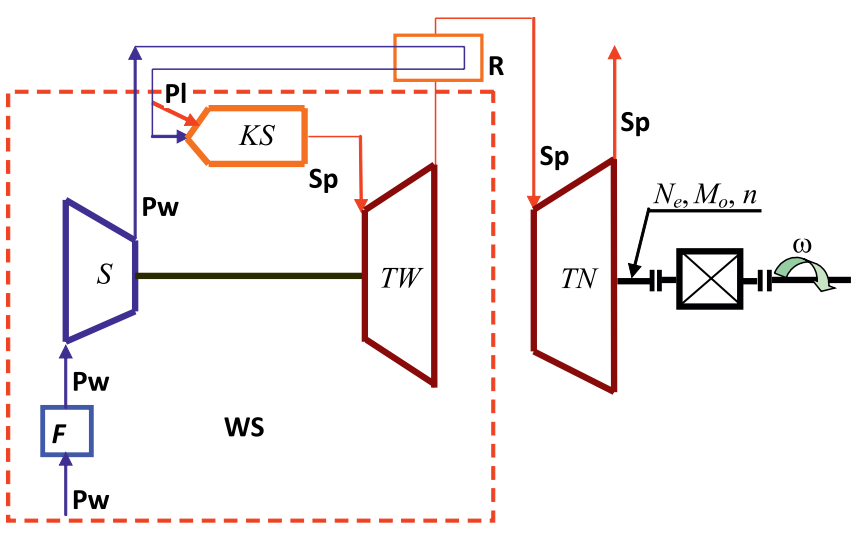

Fig. 2. Functional structure of a double shaft turbine combustion engine:

$F$ - air filter, $S$ - compressor, $K S$ - combustion chamber, $R$ - regenerative heat conveyor, TW - turbine of exhaust gas, WS - exhaust gas generator, $T N$ - drive turbine, $P l$ - fuel, $P w$ - air, $S p$ - fumes, $N_{e}$ - power output, $M_{o}$ - average torque, $n$-rotation speed, $\omega$-angular velocity.

From literature, one can ascertain, that in the case of 
turbine combustion engines $[1,14,21,25,23]$, as in the case of compression ignition engines $[5,15,16,20,21]$, conversion of chemical energy (contained in the air-fuel mixture generated in the combustion chambers) into thermal energy (heat) and the mechanical energy of the rotor of the turbine combustion engine allows the power output $N_{e}$. This power must be generated by the time $t$ required to perform the task by the engine. This means, that to complete the task at this time useful work $L_{e}=N_{e} \times t$ must be performer by any suitable turbine combustion engine. Execution of this work is the result of production of torque $\left(M_{o}\right)$ possible to measure (e.g. as a result of impulsive or optical torque meters) at a certain rotation speed $(n)$ of each turbine combustion engine. Therefore, the operation of the turbine combustion engine interpreted as energy conversion leading to the performing of useful work Le for time $t$ can be expressed as the relationship:

$$
D_{L_{e}}=\int_{0}^{t} L_{e}(\tau) \mathrm{d} \tau=2 \pi \int_{0}^{t} n(\tau) M_{o}(\tau) \tau \mathrm{d} \tau
$$

where:

$L_{e}$ - useful work, $t$ - time of operation of the turbine combustion engine, $n$ - rotation speed of the turbine propeller, $M o$ - average torque measured at the engine shaft.

Due to the fact that the useful work of the turbine combustion engine can be expressed by formula [14]

$$
L_{e}=N_{e} \cdot t=\dot{m}_{p o w} b_{j} W \eta_{K} \eta_{i} \eta_{m} t
$$

the operation of such an engine can be presented using the relationship (9) as:

$$
D_{L_{e}}=\int_{0}^{t} L_{e}(\tau) \mathrm{d} \tau=\int_{0}^{t} \dot{m}_{p o w} b_{j} W \eta_{K} \eta_{i} \eta_{m} t \mathrm{~d} \tau
$$

$$
\text { but , } b_{j}=\frac{\dot{m}_{p a l}}{\dot{m}_{p o w}}, b_{j} W=q_{p a l} \text {, }
$$

where:

$L e=$ useful work, $t$ - time of operation of the turbine combustion engine, $m_{\text {pow }}$ - air mass stream, $m_{\text {pal }}$ - fuel mass stream, $b_{j}$ - unit fuel requirement (fuel requirement for one unit of air), $W$ - calorific value of the fuel, $\eta_{K}$ - the efficiency of the combustion chamber, $\eta_{i}$ - the efficiency of the internal circuit, $\eta_{m}$ - mechanical efficiency of the turbine combustion engine, $q_{p a l}$ - heat unit contained in the fuel.

During the operation of each turbine combustion engine its condition deteriorates. This is due to the fact that the combustion of the fuel in the work areas of the engine combustion chambers and the flow generated by the exhaust turbine vane through the spaces causes the thermal and mechanical load, the most thus loaded systems is the turbine blades. Also the compressor blades of the turbine exhaust gas get contaminated (fig. 2), on which salt particles form the air get deposited. Additionally, the load of both mechanical and thermal turbine combustion engine bearings and aging of lubricating oil causes significant increase in the consumption of these tribological over time. Considerable difficulty of ensuring the proper operation of any turbine combustion engine occurs with the appearance of instability and volatility temperature and exhaust gas pressure in the combustion chamber of such an engine. It makes possible action $\left(D_{M}\right)$ of the engine decrease over time of its life. Therefore it may happen that the engine performance required $\left(D_{W}\right)$ for the job $\mathrm{Z}$ in time $\mathrm{tz}$ necessary to accomplish this task may be greater than the potential (i.e. $D_{W}>D_{M}$ ). This situation, in accordance with formula (10) and (11) was illustrated in fig. 3.

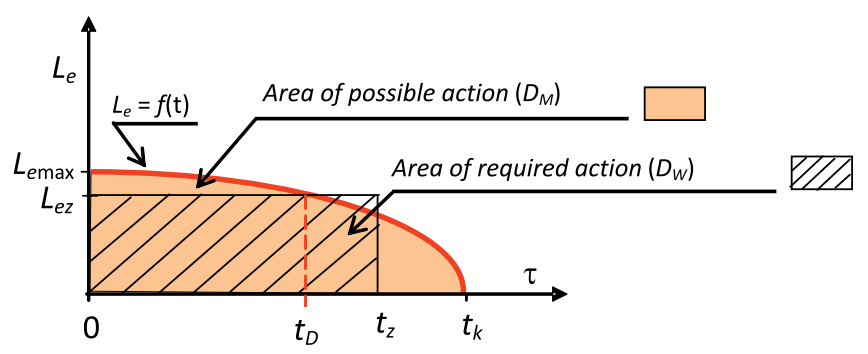

Fig. 3. Example case interpretation, where $D_{w}<D_{M}: D_{W}$ - action required, $D_{M}$ - action possible, $t_{D}$-operation time of the engine, after which the $D_{w}=D_{M}, t_{z}$ - time needed to complete the task, $t_{k}$-critical time, after the expiry of which the engine cannot operate, $t$-operation time

Decreasing function of useful work $\left(L_{e}\right)$ during operation time $(\tau)$ is (fig. 3 ) due to decrease in the total engine efficiency $\eta_{e}=\eta_{K} \times \eta_{i} \times \eta_{m}$ due to engine wear. It's obvious, because the turbine combustion engine, as any thermodynamic system, according to the second law of thermodynamics loses over time its arrangements as a result of rising energy dissipation, resulting in an increase in its entropy. In view of the rising time energy dissipation decreases the function $\eta_{e}=f(\tau)$, which is a consequence of the decrease in operating $L_{e}(\tau)$, which was incorporated in formulas (9) and (11). The reduction of the work at constant heat taken to the engine $\left(Q_{d}=Q_{p a l}=\right.$ idem), results from the following relationship [1]:

$$
L_{e(\mathrm{k})}(\tau)=\eta_{e(\mathrm{k})}(\tau) \cdot Q_{p a l}=\eta_{e(k)}(\tau) \cdot \dot{m}_{p o w(k)}(\tau) \cdot b_{j\{k\}}(\tau) \cdot W
$$

where:

$k=1,2,3, \ldots$ indexes corresponding to the respective moments $\mathrm{t}: \tau_{1}, \tau_{2}, \tau_{3}, \ldots$, for which inequalities $\eta_{e(1)}>\eta_{\mathrm{e}(2)}>$ $\eta_{\mathrm{e}(3)} \ldots$ occur, and whereint $\tau 1<\tau 2<\tau 3<\ldots$, and this leads to uneven $L_{e(1)}>L_{e(2)}>L_{e(3)} \ldots$

The field of possible action $\left(D_{M}\right)$ illustrated in fig. 3 can be calculated from the formula

$$
P_{M}=D_{M}=\int_{0}^{t_{2}} f(t) d t
$$

Whereas the field of action required $\left(D_{M}\right)$ can be calculated from the formula

$$
P_{W}=D_{W}=L_{e z} \cdot t_{z}
$$

A comparison of formulas (12) and (13) shows that 
$D_{W}<D_{M}$, which means that the turbine combustion engine is not fit for such task $\mathrm{Z}$, which may be implemented when the engine will do the work $L_{e z}$ during time $t_{z}$.

The graphical interpretation of the action shown in fig. 3 . shows that after time $t_{D}$ of engine operation, the engine cannot complete the task $Z$. On the other hand, this engine can perform all the tasks that the time to do the job Lez will be less than the time $t_{D}$, or at most equal to that time.

\section{COMMENTS AND CONCLUSIONS}

Operation of the internal combustion engine has been interpreter as providing the Energy required at a given time, which can be expressed in the form of a physical quantity with a unit of measure called joule-second.

The proposed interpretation of the operation of turbine combustion engines is the first such attempt, outlined in general. It needs to be clarified, which will not be easy because of the need for detailed identification of all types of energy that are converted during operation of the engine, and so (fig. 2) in the compressor, combustion chamber, regenerative heat conveyor, turbine of exhaust gas and drive turbine. It, that the characteristics of the propeller of the ship which is the receiver of energy supplied by the turbine combustion engine should also be taken into account.

Certainly the presented considerations about the operation of turbine combustion engines have cognitive advantages, but it is difficult now to understand of how much scientific importance they are. In turn, the utilitarian qualities are difficult to assess because of a problem with the implementation of the relevant empirical research.

Similarly, one can examine the effects of other marine equipment and even devices used in other types of transports, e.g. in road transport.

\section{LITERATURE}

1. Dzida M.: Identyfikacja przyczyn niestacjonarności oraz niestabilności temperatury I ciśnienia gazów za komorą spalania turbiny gazowej. Monografie 16 . Wydawnictwo Politechniki Gdańskiej, Gdańsk 2000.

2. Girtler J.: Possibility of valuation of operation of marine diesel engines. Journal of POLISH CIMAC, Vol 4, No 1 , 2009.

3. Girtler J.: Energy-based aspect of operation of diesel engine. COMBUSTION ENGINES No 2/2009 (137).

4. Girtler J.: Semi-Markov reliability model of gas turbine combustion engines. Proceedings of the Second International Scientific Symposium COMPOWER'2000. Politechnika Gdańska, Gdańsk 2000, s.133-140.

5. Girtler J.: A method for evaluating theoretical and real operation of diesel engines in energy conversion formulation taking into account their operating indices. Polish Maritime Research. - Vol. 18, No. 3(70), 2011, s. 31-36.

6. Girtler J.: Possibility of defining theoretical operation for diesel engines in energy terms. Combustion Engines (Silniki Spalinowe), 2011, nr 3, s. 1-9[pdf].

7. Girtler J.: Valuation method for operation of crankshaftpiston assembly in combustion engines in energy approach. Journal of POLISH CIMAC. - Vol. 6, no. 1 (2011), s. 89-98.

8. Girtler J.: The method for determining the theoretical operation of ship diesel engines in terms of energy and assessment of the real operation of such engines, including indicators of their performance. Journal of POLISH CIMAC. - Vol. 6, no. 1 (2011), s. 79-88.

9. Girtler J.: Energetyczny aspekt diagnostyki maszyn. Diagnostyka. Nr 1(45), 2008, s.149-156.

10. Girtler J.: Quantitative interpretation of energy-based systems and index of their reliability. Journal of Polish CIMAC. Vol 3, nr 1, 2008, s.87-94.

11. Girtler J.: Conception of valuation of combustion engine operation. Journal of KONES Powertrain and Transport. Vol. 15, nr 2, 2008, s. 89-96.

12. Gribbin J.: In Search of Schrödinger's Cat Quantum Physics Reality. Wyd. polskie: W poszukiwaniu kota Schrödingera. Zysk i S-ka Wydawnictwo s.c. Poznań 1997.

13. Helwitt P.G.: Fizyka wokół nas. PWN, Warszawa 2001.

14. Kowalski A.: Okrętowe turbozespoły spalinowe. WM, Gdańsk 1983.

15. Piotrowski I., Witkowski K.: Okrętowe silniki spalinowe. Wyd. TRADEMAR, Gdynia 1996.

16. Piotrkowski I., Witkowski K.: Eksploatacja okrętowych silników spalinowych. AM, Gdynia 2002.

17. Rosłanowski J.: Identification of ships propulsion engine operation by means of dimensional analysis. Journal of POLISH CIMAC, Vol. 4, No 1, 2009.

18. Rudnicki J.: Loads of ship main diesel engine in the aspect of practical assessment of its operation. Journal of POLISH CIMAC, Vol. 3, No 1, 2008.

19. Rudnicki J.: On making into account value of operational applied to ship main propulsion engine as an example. Journal of POLISH CIMAC, Vol. 4, No 1, 2009.

20. Wajand J.A., Wajand Jan T.: Tłokowe silniki spalinowe średnio- i szybkoobrotowe. WNT, Warszawa 2000. 
21. Wojnowski W.: Okrętowe siłownie spalinowe. Część I. Wyd. Akademia Marynarki Wojennej, Gdynia 1998.

22. Encyklopedia fizyki współczesnej. Praca zbiorowa. Redakcja Nauk Matematyczno-Fizycznych i Techniki Zespołu Encyklopedii i Słowników PWN. PWN, Warszawa 1983.

23. Informator European Gas Turbine Limited. England. Publication No 108/1997.

24. Leksykon naukowo-techniczny z suplementem. Praca zbiorowa. Zespół redaktorów Działu Słownictwa Technicznego WNT. WNT, Warszawa 1989.

25. McNeely M.: GE’s LMS 100, a „Game Changer”. New gas turbine combines frame and aero technology, achieves $46 \%$ efficiency. Diesel \& Gas Turbine. Worldwide. JanuaryFebruary 2004, pp.38, 40, 42 and 43.

\section{CONTACT WITH THE AUTHOR}

Marek Dzida

e-mail:dzida@pg.gda.pl

Jerzy Girtler

e-mail: jgirtl@pg.gda.pl

Gdańsk University of Technology

FACULTY OF OCEAN ENGINEERING AND SHIP

TECHNOLOGY

11/12 Narutowicza St. 80 - 233 Gdańsk

Poland 